\title{
Mantle Xenoliths from the Nikos Kimberlites on Somerset Island and the Zulu Kimberlites on Brodeur Peninsula, Baffin Island, Canada
}

\author{
Zhao, Donggao ${ }^{1}$, Essene, E.J. ${ }^{1}$, Zhang, Youxue ${ }^{1}$, and Pell, J.A. ${ }^{2}$
}

1. Department of Geological Sciences, University of Michigan, Ann Arbor, MI 48109-1063

2. NWT Geology Division, DIAND, P.O. Box 1500, Yellowknife, Canada X1A 2R3 (current address: Trivalence Mining Corporation, Suite 502, 815 Hornby St., Vancouver, Canada V6Z 2E6)

Kimberlites have been discovered in the Slave Province, on Somerset Island, and on Baffin Island near the northwestern edge of the North American craton (Pell and Atkinson, 1993). The Nikos kimberlite, near Elwin Bay on Somerset Island at $73^{\circ} 28^{\prime} \mathrm{N}$ and $90^{\circ} 58^{\prime} \mathrm{W}$, is located at the northeast end of the northeast-southwest kimberlite zone and is $\sim 1500 \mathrm{~km}$ northeast of Yellowknife, the capital of Northwest Territories. The Zulu kimberlite, the first discovery on Baffin Island, is located on the neighboring Brodeur Peninsula of Baffin Island at $73^{\circ} 14^{\prime} 47^{\prime \prime} \mathrm{N}$ and $88^{\circ} 16^{\prime} 11^{\prime \prime} \mathrm{W}$, approximately $80 \mathrm{~km}$ west of the Nikos kimberlite across the Prince Regent Inlet. The Zulu kimberlite consists of two outcrops separated by approximately 90 meters of limestone strata. Mantle xenoliths are common in the Nikos and Zulu kimberlite pipes. These xenoliths are is of particular interest because they may provide information on the nature of the upper mantle below the northwestern edge of the North American craton, and be used to evaluate diamond potential.

We have examined a variety of mantle xenoliths from the Nikos and the Zulu kimberlites, including garnet lherzolite, garnet-spinel lherzolite, spinel lherzolite, dunite, garnet websterite, spinel websterite and garnet clinopyroxenite. Alteration of the xenolith assemblages to serpentine/chlorite/talc, magnetite, and carbonates is common and more severe for xenoliths from the Zulu kimberlites. The xenoliths possess coarse protogranular texture; some may have experienced deformation reflected by, for example, kinked phlogopites. There is an oxide rich vein in one garnet-spinel lherzolite sample (JP1-X17), which consists mainly of ilmenite and phlogopite, with some clinopyroxene and orthopyroxene and rare rutile, chromite and sulfides (referred to as MORID hereafter), similar to MARID suite (mica-amphibole-rutileilmenite-diopside) and characterized by high $\mathrm{K}, \mathrm{Fe}, \mathrm{Ti}$ and $\mathrm{OH}$ components. The contact between the vein and the host is sharp. Phlogopites in the vein are usually kinked.

Mineral compositions were determined on a Cameca CAMEBAX electron microprobe at the University of Michigan. The main features of the mineral compositions are summarized in the table. There is no compositional zoning observed in olivine, orthopyroxene, clinopyroxene and garnet. However, in the MORID vein, one anhedral chromite and the coexisting ilmenite show some zonation. Mineral compositions are roughly constant within each sample, except for the xenolith with the MORID vein and one spinel lherzolite, which has two slightly different spinels. Mineral compositions of the lherzolites (including garnet lherzolite, garnet-spinel lherzolite and spinel lherzolite) are very different from those of the websterites, garnet clinopyroxenite and the MORID vein.

In the lherzolites, $\mathrm{Mg \#}(=100 \mathrm{Mg} /(\mathrm{Fe}+\mathrm{Mg})$ by atoms) of olivine ranges from 91 to 93 and is slightly higher relative to olivine in undepleted lherzolites. The Mg\# of orthopyroxene is often slightly higher than that in olivine in the same lherzolite. Clinopyroxenes are diopside with a Ca\# $(=100 \mathrm{Ca} /(\mathrm{Ca}+\mathrm{Mg}+$ $\mathrm{Fe}$ ) by atoms) of 40 to 47 . Garnets show variable $\mathrm{Mg \#}$ and $\mathrm{Cr}_{2} \mathrm{O}_{3}$; and the $\mathrm{Cr}_{2} \mathrm{O}_{3}$ content is roughly correlated with the calculated pressure for garnet-spinel lherzolites. All the lherzolitic garnets fall in the lherzolite zone in $\mathrm{Cr}_{2} \mathrm{O}_{3}$ vs. $\mathrm{CaO}$ diagram and belong to Ca-saturated lherzolitic types.

In the websterites and garnet clinopyroxenites, pyroxenes are lower in $\mathrm{Mg} \#$ and higher in $\mathrm{Al}_{2} \mathrm{O}_{3}$ than their counterparts in lherzolites, and garnets are lower in $\mathrm{Mg \#}$ than and similar in $\mathrm{Al}_{2} \mathrm{O}_{3}$ to their counterparts in lherzolites. Mg\# of the pyroxenes in some websterites and clinopyroxenites are as low as 73. Ilmenite in the garnet clinopyroxenite (JP1-X31) contains $10 \mathrm{~mol} \% \mathrm{MgTiO}_{3}$.

In the MORID vein, pyroxenes have lower $\mathrm{Mg \#}$ and higher $\mathrm{TiO}_{2}$ than those in the host, and orthopyroxene has higher $\mathrm{CaO}$ than its counterpart in the host. The $\mathrm{TiO}_{2}$ content of the garnet in the lherzolite host of the veined sample is lowest $(0.04 \%)$ in spite of the high $\mathrm{TiO}_{2}$ in the oxide-rich vein, contrary to the observation that higher $\mathrm{TiO}_{2}$ contents of garnets occur in phlogopite-bearing metasomatized xenoliths (Stiefenhofer et al., 1997). An anhedral spinel in the vein is largely uniform in 
composition (except for a decrease of $\mathrm{Cr}_{2} \mathrm{O}_{3}$ and an increase of $\mathrm{FeOt}$ near the rim) and yet different from those in the host in term of $\mathrm{FeOt}$ and $\mathrm{MgO}$ contents. All these observations suggest disequilibrium between the vein and the host, probably owing to the short duration of the metasomatic event and the subsequent entrainment of the xenolith in the eruption. Ilmenites in the vein contain $\sim 50 \mathrm{~mol} \% \mathrm{MgTiO}_{3}$, and 0.7-6.4 wt $\% \mathrm{Cr}_{2} \mathrm{O}_{3}$. An ilmenite adjacent to the spinel is gradually enriched in $\mathrm{Cr}_{2} \mathrm{O}_{3}$ approaching the spinel-ilmenite boundary. Rutile in the vein contains $95 \mathrm{wt} \% \mathrm{TiO}_{2}$ and $3.9 \mathrm{wt} \% \mathrm{Cr}_{2} \mathrm{O}_{3}$.

\begin{tabular}{lrrrrrrr}
\hline Xenolith & Mineral & $\mathrm{Mg} \#$ & $\mathrm{Ca} \#$ & $\mathrm{Al}_{2} \mathrm{O}_{3}(\mathrm{wt} \%)$ & $\mathrm{Cr}_{2} \mathrm{O}_{3}(\mathrm{wt} \%)$ & $\mathrm{Na}_{2} \mathrm{O}(\mathrm{wt} \%)$ & $\mathrm{TiO}_{2}(\mathrm{wt} \%)$ \\
\hline Gt lherzolite & $\mathrm{Opx}$ & $91-93$ & -- & $0.5-1.5$ & -- & -- & $0.0-0.1$ \\
& $\mathrm{Cpx}$ & $92-93$ & $40-47$ & $2.2-3.1$ & $1.2-2.3$ & $1.8-2.5$ & $-.2-0.3$ \\
& $\mathrm{Gt}$ & $71-85$ & $13-16$ & $20.0-22.4$ & $2.1-5.1$ & -- & $0.1-0.5$ \\
\hline Gt-Sp lherzolite & $\mathrm{Opx}$ & 93 & -- & $0.6-1.2$ & -- & -- & $0.0-0.1$ \\
& $\mathrm{Cpx}$ & $91-93$ & $43-46$ & $1.0-2.7$ & $0.4-2.4$ & $0.9-2.3$ & $0.0-1.1$ \\
& $\mathrm{Gt}$ & $70-85$ & $15-20$ & $17.5-21.6$ & $4.2-8.0$ & -- & $0.0-0.2$ \\
& $\mathrm{Sp}$ & $55-67$ & -- & $11.3-18.9$ & $48.5-62.2$ & -- & $0.2-1.1$ \\
\hline Sp lherzolite & $\mathrm{Opx}$ & 93 & -- & $0.7-1.0$ & -- & -- & $0.0-0.2$ \\
& $\mathrm{Cpx}$ & 93 & 46 & 0.7 & 3.6 & 2.0 & 0.0 \\
& $\mathrm{Sp}$ & $55-61$ & -- & $2.3-11.8$ & $58.2-65.9$ & -- & $0.1-2.9$ \\
\hline Gt websterite & $\mathrm{Opx}$ & 78 & -- & $2.6-2.4$ & -- & -- & 0.1 \\
& $\mathrm{Cpx}$ & 85 & $49-50$ & $3.8-4.6$ & $0.3-0.5$ & $1.0-1.1$ & $0.3-0.7$ \\
& $\mathrm{Gt}$ & $51-52$ & 26 & $22.4-22.8$ & $0.5-0.6$ & -- & $0.0-0.1$ \\
\hline Sp websterite & $\mathrm{Opx}$ & 88 & -- & 5.0 & -- & -- & 0.1 \\
& $\mathrm{Cpx}$ & 91 & 51 & 5.6 & 1.4 & 1.3 & 0.3 \\
& $\mathrm{Sp}$ & 63 & -- & 42.2 & 26.6 & -- & 0.0 \\
\hline Gt clinopyroxenite & $\mathrm{Cpx}$ & 73 & 46 & 2.5 & 0.0 & 0.9 & 0.4 \\
& $\mathrm{Gt}$ & 34 & 37 & 21.9 & 0.0 & -- & 0.1 \\
\hline Metasomatic vein & $\mathrm{Opx}$ & 87 & -- & 0.8 & -- & -- & 0.3 \\
& $\mathrm{Cpx}$ & 88 & 42 & 1.8 & 0.1 & 1.1 & 0.5 \\
\hline
\end{tabular}

Phlogopite is identified in kimberlite matrices, in a few lherzolite and websterite samples, and in the MORID vein. $\mathrm{TiO}_{2}$ and $\mathrm{FeOt}$ contents in phlogopites increases from lherzolites $\left(1.1 \mathrm{TiO}_{2}\right.$ and $3.0 \mathrm{wt} \%$ FeOt), to kimberlites (average 2.6 and $3.9 \mathrm{wt} \%$ ), to a garnet websterite ZL-X01 (3.6 and $4.4 \mathrm{wt} \%$ ), to the MORID vein (4.1 and $5.7 \mathrm{wt} \%$ ). The phlogopite in garnet websterite ZL-X01 also contains unusually high $\mathrm{F}(4.0 \mathrm{wt} \%$, equivalent to an $\mathrm{F} /(\mathrm{F}+\mathrm{OH})$ ratio of 0.57$)$.

The thermometer involving $\mathrm{MgSiO}_{3}$ partitioning between Opx and $\mathrm{Cpx}$ and barometer of $\mathrm{Al}$-in-Opx coexisting with garnet as recommended by Brey and Köhler (1990) were chosen for the calculations of garnet-bearing xenoliths in this study. The calculated P-T is from 25 to $60 \mathrm{kbar}$ and from 760 to $1180^{\circ} \mathrm{C}$ (Fig. 1). The P-T recalculated from the published data for other Somerset xenoliths (Jago and Mitchell, 1987; Kjarsgaard and Peterson, 1992) are also shown. The points for the Somerset xenoliths lie close to a geotherm with a heat flow of 40 and $50 \mathrm{~mW} / \mathrm{m}^{2}$ (Pollack et al., 1993). The deepest xenoliths come from a depth greater than $190 \mathrm{~km}$, where diamond is stable relative to graphite (Kennedy and Kennedy, 1976). There is no bimodal pattern of points observed in the P-T space for the Somerset mantle xenoliths, contrary to observations for the low- $T$ and high- $T$ xenoliths from Kaapvaal and Siberian cratons (Boyd, 1987; Boyd et al., 1997).

The $\mathrm{fO}_{2}$ of the xenoliths calculated by olivine-orthopyroxene-spinel oxygen barometer is from $0.7 \mathrm{log}$ units above to $1.5 \log$ units below NNO. The $\mathrm{fO}_{2}$ of the vein assemblage (JP1-X17) calculated by rutile-ilmenite oxygen barometer (Zhao et al., 1996) is about $0.4 \log$ unit below NNO. The calculated $\mathrm{fO}_{2}$ of the xenoliths is slightly more oxidizing than calculated EMOD buffer from thermodynamic data, suggesting that diamond may not be stable relative to carbonates. (Experimentally calibrated EMOD buffer curves by Wei and Luth, 1993 and by Eggler and Baker, 1983 are significantly different from each other and lie to the opposite sides of the calculated EMOD buffer.) This result re-emphasizes the fact that high enough pressure is necessary but not sufficient for the formation of diamond, low $\mathrm{fO}_{2}$ is also necessary. 


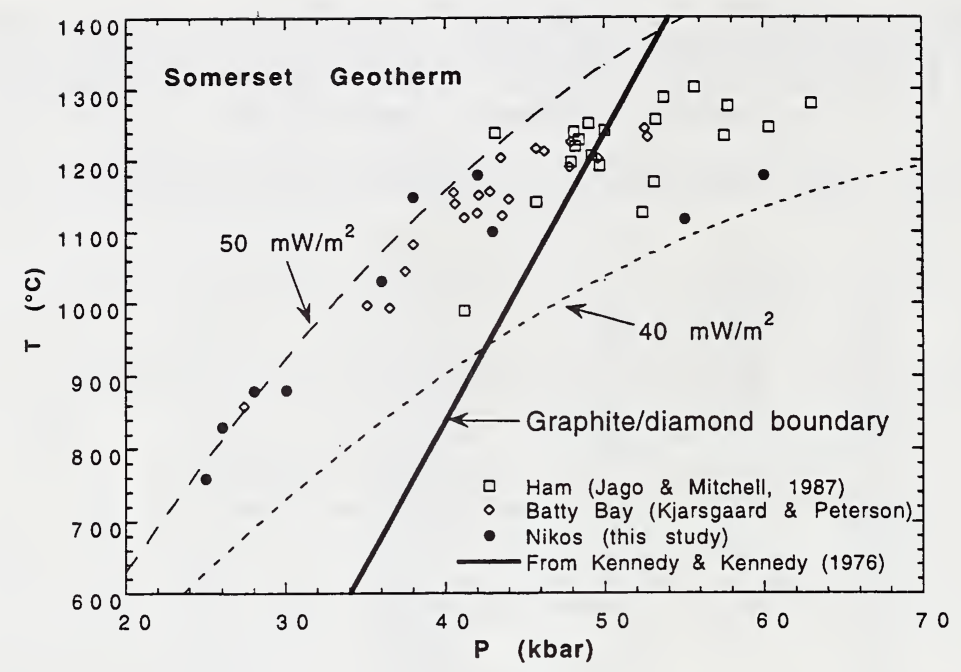

\section{References}

Boyd, F.R., 1987, High- and low-temperature garnet peridotite xenoliths and their possible relation to the lithosphere-asthenosphere boundary beneath southern Africa. In: Nixon, P.H. (ed.) Mantle xenoliths, Wiley, Chichester, p. 403-412.

Boyd, F.R., Pokhilenko, N.P., Pearson, D.G., Mertzman, S.A., Sobolev, N.V., and Finger, L.W., 1997, Composition of the Siberian cratonic mantle: evidence from Udachnaya peridotite xenoliths: Contrib. Mineral. Petrol., 128, p. 228-246.

Brey, G., and Köhler, T., 1990, Geothermobarometry in four-phase lherzolite II: new thermobarometers, and practical assessment of existing thermobarometers: J. Petrol., 31, p. 1353-1378. Eggler, D. H., and Baker, D. R., 1983, Reduced volatiles in the system C-O-H: implications to mantle melting, fluid formation, and diamond genesis. In: Manghanni, M. and Akimoto, S. (eds.) High Pressure Research and Applications in Geophysics, p. 237-250.

Jago, B. C., and Mitchell, R. H., 1987, Ultrabasic xenoliths from the Ham kimberlite, Somerset Island, Northwest Territories: Canadian Mineral., 25, p. 515-525.

Kennedy, C.S., and Kennedy, G.C., 1976, The equilibrium boundary between graphite and diamond: J. Geophys. Res., 81, p. 2467-2470.

Kjarsgaard, B. A., and Peterson, T. D., 1992, Kimberlite-derived ultramafic xenoliths from the diamond stability field: a new Cretaceous geotherm for Somerset Island, Northwest Territories: Current Research, Part B, Geol. Surv. Can. Pap. 92-1B, p. 1-6.

Pell, J.A., and Atkinson, D., 1993, Northwest Territories kimberlites and diamonds: exploration highlights and implications. In: Mid-Continental Diamonds Symposium, Geological Association of Canada Mineral Deposits Division, p. 89-93.

Pollack, H.N., Hurter, S.J., and Johnson, J.R., 1993, Heat flow from the Earth's interior: analysis of the global data set: Rev. Geophys., 31, p. 267-280.

Stiefenhofer, J., Viljoen, K.S., and Marsh, J.S., 1997, Petrology and geochemistry of peridotite xenoliths from the Letlhakane kimberlites, Botswana: Contrib. Mineral. Petrol., 127, p. 147-158.

Wei, K., and Luth, R. W., 1993, Calibration of oxidation-reduction reactions at $1000-1400^{\circ} \mathrm{C}$ and 5-9 $\mathrm{GPa}$ in the multianvil apparatus: Eos, 74, p. S321.

Zhao, D., Essene, E.J., and Zhang, Y., 1996, Oxygen fugacities in ilmenite-rutile assemblages using $2 \mathrm{Fe}_{2} \mathrm{O}_{3}(\mathrm{ilm})+4 \mathrm{TiO}_{2}=4 \mathrm{FeTiO}_{3}(\mathrm{ilm})+\mathrm{O}_{2}$ : Eos, 77 , p. F828. 